\title{
Controlled Radical Polymerization of Vinyl Acetate with \\ Cyclopentadienyl Chromium $\beta$-Diketiminate Complexes: ATRP vs. OMRP
}

Yohan Champouret, ${ }^{\mathrm{a}}$ K. Cory MacLeod, ${ }^{\mathrm{b}}$ Kevin M. Smith, ${ }^{\mathrm{b}}$ Brian O. Patrick, ${ }^{\mathrm{c}}$ Rinaldo

$$
\text { Polia }^{\mathrm{a} d *}
$$

${ }^{a}$ CNRS; LCC (Laboratoire de Chimie de Coordination); Université de Toulouse; UPS,

INPT; 205, route de Narbonne, F-31077 Toulouse, France

${ }^{b}$ Department of Chemistry, University of British Columbia Okanagan, 3333

University Way, Kelowna, BC, Canada V1V 1V7

${ }^{c}$ Department of Chemistry, University of British Columbia, Vancouver, British

Columbia, Canada V6T 1Z1

${ }^{d}$ Institut Universitaire de France, 103, bd Saint-Michel, 75005 Paris, France 


\section{Abstract}

The ability of compounds $\mathrm{CpCr}^{\mathrm{II}}\left(\right.$ nacnac $\left.^{\mathrm{Ar}, \mathrm{Ar}}\right)(\mathrm{Ar}=\mathrm{Dipp}, \mathbf{1} ; \mathrm{Xyl}, 2)$ to catalyze the atom transfer radical polymerization (ATRP) of vinyl acetate has been explored using methyl 2-chloropropionate as initiator. Polymerizations were also carried out under reverse ATRP conditions with thermal initiation by 2,2'-azobis(4-methoxy2,4-dimethylvaleronitrile) (V-70) in the presence of compounds $\mathrm{CpCr}^{\mathrm{III}} \mathrm{Cl}\left(\right.$ nacnac $\left.^{\mathrm{Ar}, \mathrm{Ar}}\right)$ $(\mathrm{Ar}=$ Dipp, $\mathbf{3} ; \mathrm{Xyl}, \mathbf{4})$. All data suggest that these processes are in fact proceeding by organometallic mediated radical polymerization (OMRP). Stoichiometric reactions between complex 2 and the chlorinated compounds $\mathrm{CH}_{3} \mathrm{CH}(\mathrm{Cl}) \mathrm{COOCH}_{3}$, $\mathrm{ClCH}_{2} \mathrm{COPh}, \mathrm{CH}_{3} \mathrm{CHClOOCCH}_{3}, \mathrm{ClCH}_{2} \mathrm{OOC} t \mathrm{Bu}$, and $\mathrm{ClCH}_{2} t \mathrm{Bu}$ in the absence of monomer aid in the interpretation of the polymerization results. The first two substrates show rapid 1-electron oxidative additions to generate $\mathbf{4}$ and $\mathrm{O}$-bonded $\mathrm{Cr}^{\mathrm{III}}$ products, whereas the $3^{\text {rd }}$ and $4^{\text {th }}$ substrate add much more slowly to generate 4 and C-bonded $\mathrm{Cr}^{\mathrm{III}}$ products and $\mathrm{ClCH}_{2} t \mathrm{Bu}$ does not react. DFT calculations on the competitive radical trapping processes (activation barriers and relative stability of the products) confirms the kinetic and thermodynamic preference for metal-carbon bond formation to generate the dormant species of OMRP. 


\section{Introduction}

There has been considerable interest in recent years in the controlled polymerization of vinyl acetate (VAc), since the resulting polymers as well as statistical and block copolymers have many different applications, related to the subsequent conversion of the hydrophobic acetate functions to hydrophilic alcohol functions. This monomer can only be polymerized by the radical pathway but controlled chain growth is difficult due to the relatively high reactivity of the propagating radical species compared to more tractable substrates such as styrene or acrylates. $^{1}$ Among various methods, comprising degenerate transfer with dithiocarbamates, ${ }^{2,3}$ xanthates, ${ }^{4,5}$ and organotellurium and -antimony compounds, ${ }^{6}$ the use of cobalt complexes either in a degenerative transfer mode ${ }^{7,8}$ or in a reversible termination mode ${ }^{9,10}$ (organometallic mediated radical polymerization, or OMRP) has proven to afford the best level of control, with polydispersity indexes below 1.1 in certain cases. ${ }^{11}$ In the OMRP mechanism, unwanted bimolecular radical coupling reactions are effectively prevented by the reversible formation and homolytic cleavage of a metal-alkyl bond (Scheme 1). ${ }^{12}$

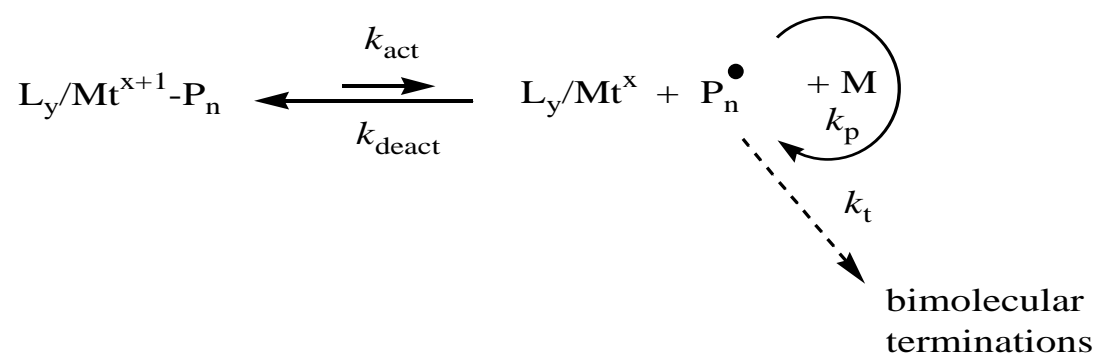

\section{Scheme 1}


On the basis of the well established ability of $\mathrm{Cr}^{\mathrm{II}}$ complexes such as $\left[\mathrm{Cr}\left(\mathrm{H}_{2} \mathrm{O}\right)_{6}\right]^{2+}$ or solvated $\mathrm{CrCl}_{2}$ to effectively trap organic radicals at close to diffusion controlled rates to form $\mathrm{Cr}^{\mathrm{III}}$-alkyl species, ${ }^{13}$ we have recently tested a few high spin organometallic $\mathrm{Cr}^{\mathrm{II}}$ complexes of type $\mathrm{CpCr}\left(\right.$ nacnac $\left.^{\mathrm{Ar}, \mathrm{Ar}}\right)$, where nacnac ${ }^{\mathrm{Ar}, \mathrm{Ar}}$ is a bulky aryl-substituted $\beta$-diketiminato ligand, $\operatorname{ArNC}\left(\mathrm{CH}_{3}\right) \mathrm{CHC}\left(\mathrm{CH}_{3}\right) \mathrm{NAr}$, as moderating agents in VAc polymerization and have shown that they can indeed trap the growing PVAc radical chains effectively and reversibly. ${ }^{14,15}$ The polymerization at $30^{\circ} \mathrm{C}$ initiated by the thermally labile diazo compound 2,2'-azobis(4-methoxy2,4-dimethylvaleronitrile) $\left(\mathrm{V}-70, \mathrm{t}_{1 / 2}=10 \mathrm{~h}\right)$ in the presence of the more sterically hindered complex with $\mathrm{Ar}=\mathrm{Ar}{ }^{\prime}=\mathrm{C}_{6} \mathrm{H}_{3} i \mathrm{Pr}_{2}-2,6$ or Dipp, 1, was relatively fast $(70 \%$ conversion in $46 \mathrm{~h}$ using VAc/V-70/1=500/0.8/1), albeit much slower than the control experiment carried out without $\mathrm{Cr}$ complex, but poorly controlled $\left(M_{\mathrm{w}} / M_{\mathrm{n}}=1.8\right)$ consistent with a relatively slow trapping rate. The less sterically hindered system with $\mathrm{Ar}=\mathrm{Ar}{ }^{\prime}=\mathrm{C}_{6} \mathrm{H}_{3} \mathrm{Me}_{2}-2,6$ or $\mathrm{Xyl}, \mathbf{2}$, on the other hand, revealed a much less reversible OMRP trapping process, since polymerization stopped at a conversion of ca. $12 \%$ at $50^{\circ} \mathrm{C}$ and did not progress further even at $90{ }^{\circ} \mathrm{C} .{ }^{14}$ Further work using the neopentyl compound $\mathrm{CpCr}{ }^{\mathrm{III}}\left(\right.$ nacnac $\left.{ }^{\mathrm{Xyl}, \mathrm{Xyl}}\right)\left(\mathrm{CH}_{2} \mathrm{CMe}_{3}\right)$ as a single-molecule initiator, however, showed activation and sustained (albeit very slow) polymerization at room temperature with better control $\left(M_{\mathrm{w}} / M_{\mathrm{n}}=1.46\right.$ at $14 \%$ conversion after $\left.400 \mathrm{~h}\right)$, but complete deactivation occurred at higher temperatures $\left(>50^{\circ} \mathrm{C}\right)$, this being traced to a decomposition process with formation of the acetate complex $\mathrm{CpCr}^{\mathrm{III}}\left(\right.$ nacnac $\left.^{\mathrm{Xyl}, \mathrm{Xyl}}\right)\left(\mathrm{O}_{2} \mathrm{CCH}_{3}\right){ }^{15}$ 
We are also interested in the interplay between ATRP and OMRP mechanisms for controlled chain growth. ${ }^{12}$ When the metal complex in the reduced state is able to abstract a halogen atom from a halogen-terminated dormant chain, yielding the chain carrying radical and an oxidized metal complex, a moderating equilibrium based on this atom transfer process can also be installed. For the half-sandwich $\mathrm{CpCr}$ (nacnac) system, this ATRP activation/deactivation equilibrium is possible since the corresponding chloro complexes of $\mathrm{Cr}^{\mathrm{III}}$ are known, ${ }^{15-17}$ notably $\mathrm{CpCr}^{\mathrm{III}}\left(\right.$ nacnac $\left.^{\mathrm{Ar}, \mathrm{Ar}}\right) \mathrm{Cl}$ with $\mathrm{Ar}=\operatorname{Ar}{ }^{\prime}=\operatorname{Dipp}(3)^{16}$ or Xyl (4). ${ }^{15}$ The first such interplay was reported for the polymerization of styrene mediated by half-sandwich Mo complexes, $\mathrm{CpMo}^{\mathrm{III}} \mathrm{Cl}_{2} \mathrm{~L}_{2}\left(\mathrm{~L}_{2}=\left(\mathrm{PMe}_{3}\right)_{2}\right.$, dppe, or $\left.\eta^{4}-\mathrm{C}_{4} \mathrm{H}_{6}\right){ }^{18}$

The interplay of the two trapping processes is schematically shown in the free energy diagram of Figure 1. When the polymerization is carried out under OMRP conditions (either from the reduced complex $\mathrm{Mt}^{\mathrm{n}}$ and an external radical source such as V-70, or from an organometallic initiator $\mathrm{Mt}^{\mathrm{n}+1}-\mathrm{R}_{0}$ ), no interplay with ATRP can occur if the metal complex is devoid of halogen ligand. This is the case for the above mentioned VAc polymerization mediated by complexes $\mathbf{1}$ and $\mathbf{2}$. On the other hand, when the polymerization is carried out under ATRP conditions $\left(\mathrm{Mt}^{\mathrm{n}}+\mathrm{R}_{0}-\mathrm{X}\right)$, or the so-called "reverse" ATRP conditions $\left(\mathrm{Mt}^{\mathrm{n}+1}-\mathrm{X}\right.$ and an external source of $\mathrm{R}_{0}{ }^{\bullet}$ such as $\mathrm{V}-70$ ), then the active chain may be trapped both by the $\mathrm{Mt}^{\mathrm{n}+1}-\mathrm{X}$ complex generated during the activation (under ATRP conditions) or initially present (under reverse ATRP conditions), giving rise to the ATRP equilibrium, or by $\mathrm{Mt}^{\mathrm{n}}$ initially present (under ATRP conditions) or generated by the initial ATRP trapping (under reverse 
ATRP conditions), giving rise to the OMRP equilibrium. For each type of activation/deactivation equilibrium, three energetic parameters are of importance: a thermodynamic parameter $\Delta G$ and the two activation barriers $\Delta G^{\ddagger}$ act and $\Delta G^{\ddagger}$ deact for the activation and deactivation process $\left(\Delta G=\Delta G^{\ddagger}\right.$ act $-\Delta G^{\ddagger}$ deact $)$, as shown in Figure $1 a$.

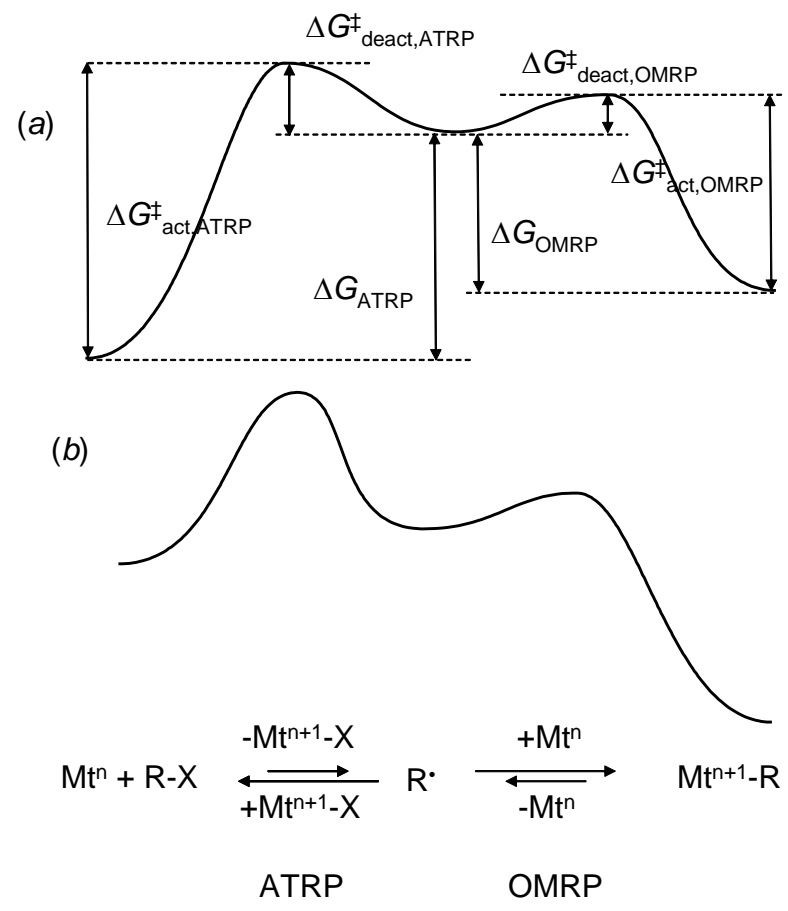

Figure 1. Schematic energy diagrams for the interplay of ATRP and OMRP trapping. (a) Case of dominant ATRP. (b) Case of dominant OMRP.

When ATRP trapping is thermodynamically more favorable (case of Figure 1a), the dormant chain prevalently contains halogenated chain ends. Different situations have been described, where $\Delta G_{\mathrm{ATRP}} \gg \gg G_{\mathrm{OMRP}}$, as in the case of copper systems where control is essentially only insured by ATRP, ${ }^{19}$ or $\Delta G_{\text {ATRP }}>\Delta G_{\text {OMRP }}$ (ATRP dormant species marginally more stable than the OMRP dormant species), as in the 
case of some molybdenum ${ }^{18}$ and osmium systems. ${ }^{20,21}$ In the latter cases, the two trapping equilibria cooperate during the ATRP process and a more or less pronounced degree of control can also be observed under pure OMRP conditions.

It is also possible to envisage, however, a case where OMRP trapping dominates $\left(\Delta G_{\mathrm{ATRP}}<\Delta G_{\mathrm{OMRP}}\right)$, as shown in Figure $1 b$. This situation has not yet been highlighted, to the best of our knowledge. We would like to present here the first example of this situation. Chromium(II) complexes are known to possess a strong reducing power, thus the $\mathrm{Cr}^{\mathrm{III}}-\mathrm{Cl}$ bond may be expected to be rather strong in a homolytic sense, compared for instance to a $\mathrm{Fe}^{\mathrm{III}}-\mathrm{Cl}$ or $\mathrm{Cu}^{\mathrm{II}}-\mathrm{Cl}$ bond. In turn, this is expected to reduce the $\Delta G_{\mathrm{ATRP}}$ value for a given $\mathrm{R}-\mathrm{X}$ system, since $\Delta H_{\mathrm{ATRP}}=$ $\left[\mathrm{BDE}(\mathrm{R}-\mathrm{X})-\mathrm{BDE}\left(\mathrm{Mt}^{\mathrm{n}+1}-\mathrm{X}\right)\right]^{12}$ while $\Delta S_{\mathrm{ATRP}}$ should be small. Vinyl acetate is a monomer that leads to rather strong $\mathrm{C}-\mathrm{X}$ bonds for $\mathrm{X}=\mathrm{Cl}$ or $\mathrm{Br}^{22}$ In order to activate dormant chains with strong $\mathrm{C}-\mathrm{X}$ bonds, metal complexes capable of yielding stronger $\mathrm{Mt}^{\mathrm{n}+1}-\mathrm{X}$ bonds are necessary. Under these circumstances, stronger $\mathrm{Mt}^{\mathrm{n}+1}-\mathrm{C}$ bonds should also be formed, likely leading to irreversible OMRP trapping, unless the $\mathrm{Mt}^{\mathrm{n}+1}-\mathrm{C}$ bond strength is attenuated by steric interactions and this is indeed the case for the $\mathrm{CpCr}^{\mathrm{II}}$ (nacnac) system, as demonstrated in our previous contributions. ${ }^{14,15}$

\section{Experimental Section}

Materials. All procedures, unless otherwise stated, were carried out under dry, oxygen-free argon or nitrogen, using standard Schlenk and glove box techniques. 
Solvents were dried by using the method of Grubbs ${ }^{23}$ or distilled under argon from appropriate drying agents and degassed by three freeze-vacuum-thaw cycles prior to use. ${ }^{24}$ Celite (Aldrich) was dried overnight at $110{ }^{\circ} \mathrm{C}$ before being evacuated and then stored under argon or nitrogen. Vinyl acetate (VOAc, $99 \%$, Alfa Aesar) was passed through a neutral alumina column to remove the stabilizer, dried over calcium hydride, distilled at $90{ }^{\circ} \mathrm{C}$, degassed by three freeze-vacuum-thaw cycles and stored under argon or nitrogen at $-20^{\circ} \mathrm{C} .2,2^{\prime}$-azobis(4-methoxy-2,4-dimethylvaleronitrile) (V-70, 96\%, Wako) was used as received. Acetophenone, methyl 2-chloropropionate, chloromethyl pivalate and neopentyl chloride were purchased from Aldrich, distilled under reduced pressure and/or degassed by three freeze-vacuum-thaw cycles before being used. Methyl propionate, phenacyl chloride and $\mathrm{KN}\left(\mathrm{SiMe}_{3}\right)_{2}$ were purchased from Aldrich and used as received. Complexes $\mathrm{CpCr}^{\mathrm{II}}\left(\operatorname{nacnac}^{\mathrm{Ar}, \mathrm{Ar}}\right)(\mathrm{Ar}=\mathrm{Dipp}, \mathbf{1} ; \mathrm{Xyl}, 2),{ }^{14}, 16$ $\mathrm{CpCr}^{\mathrm{III}}\left(\right.$ nacnac $\left.^{\mathrm{Ar}, \mathrm{Ar}}\right) \mathrm{Cl}(\mathrm{Ar}=\mathrm{Dipp}, \mathbf{3} ; \mathrm{Xyl}, 4),{ }^{15}, 16 \mathrm{CpCr}^{\mathrm{III}}\left(\operatorname{nacnac}^{\mathrm{Xyl}, \mathrm{Xyl}}\right) \mathrm{I},{ }^{17}$ and $\mathrm{CH}_{3} \mathrm{CH}(\mathrm{Cl}) \mathrm{OOCCH}_{3}{ }^{25}$ were prepared according to literature procedures. $\mathrm{K}\left[\mathrm{OC}(\mathrm{Ph})=\mathrm{CH}_{2}\right]$ and $\mathrm{K}\left[\mathrm{OC}\left(\mathrm{OCH}_{3}\right)=\mathrm{CHCH}_{3}\right]$ were prepared according to literature procedures outlining the preparation of similar potassium enolate compounds. ${ }^{26}$

Characterizations. A Varian Cary 100 Bio UV-visible spectrophotometer was used to conduct measurements using a specially constructed cell for air-sensitive samples: a Kontes Hi-Vac Valve with PTFE plug was attached by a professional glassblower to a Hellma $10 \mathrm{~mm}$ path length quartz absorption cell with a quartz-to-glass graded seal. Size exclusion chromatography (SEC) of poly (vinyl acetate) was carried out in filtered THF (flow rate: $1 \mathrm{ml} / \mathrm{min}$ ) at $35^{\circ} \mathrm{C}$ on a $300 \times 7,5$ 
mm PL gel 5 micrometer mixed-D column (polymer laboratories), equipped with multiangle light scattering (minidawn Tristar, Wyatt Technology Corporation) and refractive index (RI2000, Sopares) detectors, with a waters column pack $(300 \times 7,5 \mathrm{~mm}$,

ultrastyragel 104,103,100 $\mathrm{A}$ ), equipped with multiangle light scattering (miniDawn Tristar,Wyatt Technology Corp.) and refractive index (waters 410) detectors or at $30^{\circ} \mathrm{C}$ on a Polymer Labs PL-GPC 50 plus (two PLgel mixC columns in series) with a PL-AS RT autosampler and PL-RI detector. The isolated polymer samples were dissolved in THF and the polymer solutions were filtered (pore size $=0.45 \mu \mathrm{m}$ ) before chromatographic analysis. The columns were calibrated against linear polystyrene standards (Polymer Laboratories).

General procedures for the radical polymerization of vinyl acetate. (a) ATRP procedure: $\mathrm{Cr}^{\mathrm{II}}+$ methyl 2-chloropropionate. All polymerizations were conducted following the same experimental protocol. As a representative example, the Schlenk tube was charged with complex 1 (36 mg, $0.086 \mathrm{mmol}, 1$ equiv) and methyl 2-chloropropionate ( $5 \mu \mathrm{L}, 0.043 \mathrm{mmol}, 0.5$ equiv), followed by the addition of degassed vinyl acetate ( $4 \mathrm{~mL}, 43 \mathrm{mmol}, 500$ equiv). The Schlenk tube was degassed by three freeze-vacuum-thaw cycles and then immersed in an oil bath preheated at $50^{\circ} \mathrm{C}$. At the desired time, the Schlenk flask was rapidly cooled to room temperature by immersion into iced water before sample withdrawal. The monomer conversion was determined gravimetrically after removal of the unconverted monomer under reduced pressure and the resulting residue was used for SEC characterization.

(b) Reverse ATRP procedure: $\mathbf{C r}{ }^{\mathrm{III}} \mathbf{C l}+\mathrm{V}-70$. All polymerizations were 
conducted following the same experimental protocol. A typical experiment is described here as a representative example with complex 4, VAc and 0.5 eq. of V-70 $(\mathrm{Cr}: \mathrm{V}-70: \mathrm{VAc}=1: 0.5: 500)$. All operations were carried out under a protective argon atmosphere. Complex 4 (39.3 mg, $0.086 \mathrm{mmol}, 1$ equiv) and V-70 (13.2 mg 0.043 mmol, 0.5 eq.) were introduced in a Schlenk tube, followed by the addition of degassed vinyl acetate ( $4 \mathrm{~mL}, 43 \mathrm{mmol}, 500$ equiv). The Schlenk tube was degassed by three freeze-vacuum-thaw cycles and then immersed in an oil bath preheated at $50{ }^{\circ} \mathrm{C}$. At the desired time, the Schlenk flask was rapidly cooled to room temperature by immersion into iced water before sample withdrawal. The monomer conversion was determined gravimetrically after removal of the unconverted monomer under reduced pressure, and the resulting residue was used for SEC characterization.

(c) From a $\mathrm{Cr}^{\mathrm{III}}$-enolate complex. Compounds $\mathrm{CpCr}^{\mathrm{III}}\left(\operatorname{nacnac}^{\mathrm{Xyl}, \mathrm{Xyl}}\right) \mathrm{I}(151 \mathrm{mg}$, $0.275 \mathrm{mmol})$ and $\mathrm{K}\left[\mathrm{OC}\left(\mathrm{OCH}_{3}\right)=\mathrm{CHCH}_{3}\right](42.3 \mathrm{mg}, 0.335 \mathrm{mmol}, 1.22$ equiv $)$ were placed in a Schlenk flask followed by the addition of toluene $(15 \mathrm{~mL})$. The mixture was stirred overnight at room temperature at which point the solvent was evaporated in vacuo. The residue was extracted with hexanes $(10 \mathrm{~mL})$ and filtered through Celite (UV/vis: $\lambda_{\max }=397 \mathrm{~nm}, 635 \mathrm{~nm}$ ). The green solution was cooled to $-35{ }^{\circ} \mathrm{C}$ to yield $25.1 \mathrm{mg}$ of compound $\mathrm{CpCr}^{\mathrm{III}}\left(\right.$ nacnac $\left.^{\mathrm{Xyl}, \mathrm{Xyl}}\right)\left[\mathrm{OC}\left(\mathrm{OCH}_{3}\right)=\mathrm{CHCH}_{3}\right](18 \%)$. This batch was then dissolved in VAc $(2 \mathrm{~mL})$. Stirring at room temperature for $54 \mathrm{~h}$ and then warming to $50^{\circ} \mathrm{C}$ for $21.5 \mathrm{~h}$ did not result in any polymerization process.

Synthesis of compound $\operatorname{CpCr}\left(\operatorname{nacnac}^{\mathrm{Xyl}, \mathrm{Xyl}}\right)\left[\mathrm{OC}(\mathbf{P h})=\mathrm{CH}_{2}\right]$, 5. A toluene $(1$ $\mathrm{mL})$ suspension of $\mathrm{K}\left[\mathrm{OC}(\mathrm{Ph})=\mathrm{CH}_{2}\right](16.9 \mathrm{mg}, 0.107 \mathrm{mmol}, 1.11$ equiv $)$ was reacted 
with $\mathrm{CpCr}^{\mathrm{III}}\left(\right.$ nacnac $\left.^{\mathrm{Xyl}, \mathrm{Xyl}}\right) \mathrm{I}(52.9 \mathrm{mg}, 0.0963 \mathrm{mmol})$ dissolved in toluene $(4 \mathrm{~mL})$ in a Schlenk flask overnight at room temperature. The solvent was evaporated in vacuo, the residue was extracted with hexanes $(2 \mathrm{~mL})$, filtered through Celite and cooled to $-35{ }^{\circ} \mathrm{C}$ for 3 days to yield crystals of $5(5.6 \mathrm{mg}, 11 \%)$ suitable for $\mathrm{x}$-ray crystallographic analysis. Due to the presence of co-crystallized iodide starting material, satisfactory elemental analysis for $\mathbf{5}$ was not obtained. UV/vis (hexanes; $\lambda_{\max }$, $\left.\mathrm{nm}\left(\varepsilon, \mathrm{M}^{-1} \mathrm{~cm}^{-1}\right)\right): 407$ (7600), $607(500)$.

X-ray characterization of compound 5. A single crystal of compound $\mathbf{5}$ was mounted on a glass fiber and centered on the optical path of a Bruker X8 APEX II diffractometer with graphite-monochromated Mo $\mathrm{K} \alpha$ radiation. The data were collected at a temperature of $-100.0 \pm 0.1{ }^{\circ} \mathrm{C}$ in a series of $\phi$ and $\omega$ scans in $0.5^{\circ}$ oscillations. Data were collected and integrated using the Bruker SAINT software package $^{27}$ and were corrected for absorption effects using the multiscan technique $(\text { TWINABS) })^{28}$ and for Lorentz and polarization effects. The structure was solved by direct methods with SIR92. ${ }^{29}$ Compound 5 crystallizes with $10 \quad \%$ $\mathrm{CpCr}^{\mathrm{III}}\left(\right.$ nacnac $\left.^{\mathrm{Xyl}, \mathrm{Xyl}}\right) \mathrm{I}$ starting material in the crystal lattice. The material crystallizes as a two component split crystal with the two components related by a $33^{\circ}$ rotation about the $\left(\begin{array}{lll}1 & 0 & 0\end{array}\right)$ real axis. Data were integrated for both twin components, including both overlapped and non-overlapped reflections. The structure was solved using non-overlapped data from the major twin component. Subsequent refinements of $\mathbf{5}$ were carried out using an HKLF 5 format data set containing complete from component 1 and all overlapped reflections from component 2 . The batch scale 
refinement showed a roughly 82:18 ratio between the major and minor twin components. All non-hydrogen atoms were refined anisotropically. All hydrogen atoms were placed in calculated positions but were not refined. All refinements were performed using the SHELXTL crystallographic software package of Bruker-AXS. ${ }^{30}$ The molecular drawing was generated by the use of ORTEP-3. ${ }^{31}$

Computational details. QM/MM calculations were carried out by use of the Gaussian03 suite of programs ${ }^{32}$ with use of the B3LYP functional ${ }^{33}$ within the DFT methodology for the QM part and of the $\mathrm{UFF}^{34}$ for the MM part. The basis set chosen for the QM calculations comprised the 6-31G* set for the $\mathrm{H}, \mathrm{C}, \mathrm{N}, \mathrm{O}$ and $\mathrm{Cl}$ atoms, and the SDD set, which includes a pseudopotential, augmented by an f polarization function with the optimized ${ }^{35} 1.941$ coefficient for the $\mathrm{Cr}$ atom. The cutoff between the QM and MM parts was placed at the level of the Ar-N bonds, with the $\mathrm{NC}(\mathrm{Me}) \mathrm{CHC}(\mathrm{Me}) \mathrm{N}$ diketiminato moiety being treated quantomechanically together with the $\mathrm{Cr}$ atom, the $\mathrm{Cp}$ ring, the $\mathrm{Cl}$ ligand and the $\mathrm{CH}(\mathrm{OAc}) \mathrm{CH}_{3}$ fragment, while the entire aryl substituents were handled at the MM level. The input geometry of compound $\mathbf{3}$ was obtained from the crystallographically characterized compound ${ }^{15}$ and those of the related systems with $\mathrm{Ar}=\mathrm{Ph}$ or Dipp were adapted from it. For the $\mathrm{Cl}$-atom transfer transition states, the input geometries were constructed following an initial scan of the $\mathrm{Cr}-\mathrm{Cl}$ distance with the $\mathrm{Cl}-\mathrm{CH}(\mathrm{OAc}) \mathrm{CH}_{3}$ molecule being initially placed next to the $\mathrm{CpCr}^{\mathrm{II}}\left(\right.$ nacnac $\left.{ }^{\mathrm{Ar}, \mathrm{Ar}}\right)$ system in a direction suitable for the eventual formation of the $\mathrm{Cr}-\mathrm{Cl}$ bond, with a linear $\mathrm{Cr} \cdots \mathrm{Cl}-\mathrm{C}$ angle. Spin contamination was negligible, all calculations converging with $\left\langle\mathrm{S}^{2}\right\rangle$ close to the expected values $(3.75$ 
for the quartet state of $\mathrm{Cr}^{\mathrm{III}}, 6.00$ for the quintet state of the atom transfer transition states). The maximum deviations were 3.7966 for the quartet states $(\mathrm{Ar}=\mathrm{Dipp})$ and 6.0848 for the quintet state $(\mathrm{Ar}=\mathrm{Dipp})$. The calculations on the $\mathrm{Cr}^{\mathrm{II}}$ complexes $\mathrm{CpCr}^{\mathrm{II}}\left(\right.$ nacnac $\left.^{\mathrm{Ar}, \mathrm{Ar}}\right)$, on the organometallic dormant complexes $\mathrm{CpCr}^{\mathrm{III}}\left(\right.$ nacnac $\left.^{\mathrm{Ar}, \mathrm{Ar}}\right)$ (CHMeOAc), and on the transition states between them for (CHMeOAc) trapping ( $\mathrm{Ar}$ $=\mathrm{Ph}, \mathrm{Xyl}$, Dipp) have previously been described at the same level of theory. ${ }^{15}$ Frequency calculations confirmed the nature of the optimized geometries as global energy minima. The electronic energies were corrected by the ZPVE term and converted to enthalpy and to Gibbs free energies at $25^{\circ} \mathrm{C}$ on the basis of the ideal gas and harmonic oscillator approximations.

\section{Results}

(a) ATRP of VAc mediated by complexes 1 and 2

Polymerizations of VAc were carried out in the presence of compounds $\mathbf{1}$ or $\mathbf{2}$ as catalysts under standard ATRP conditions with $\mathrm{CH}_{3} \mathrm{CH}(\mathrm{Cl}) \mathrm{COOCH}_{3}$ as initiator. Compound $\mathrm{CH}_{3} \mathrm{CH}(\mathrm{Cl}) \mathrm{COOCH}_{3}$ was chosen as an initiator because its $\mathrm{C}-\mathrm{Cl}$ bond is weaker than that of the ATRP PVAc-Cl dormant chain, ${ }^{22}$ thus ensuring a fast consumption of initiator. Although bromide compounds are typically preferred as initiators for ATRP, we selected a reactive chloro derivative in this case because the expected product of atom transfer, the $\mathrm{Cr}^{\mathrm{III}}$ chloride complexes $\mathbf{3}$ and $\mathbf{4}$, also exist and can been independently used to install the same atom transfer equilibrium by reverse 
ATRP (vide infra). The operating conditions and conversion results are given in Figure 2. Note that these reactions were carried out at $50^{\circ} \mathrm{C}$. In the presence of 1 equiv of initiator per $\mathrm{Cr}^{\mathrm{II}}$ atom, monomer consumption was initially rapid but subsequently reached a plateau at $26 \%$ and $16 \%$ conversion with compounds $\mathbf{1}$ and $\mathbf{2}$, respectively. The efficiency factor is very low (ca. 0.11 in both experiments) and the polymer obtained has a relatively narrow polydispersity $\left(\mathrm{M}_{\mathrm{w}} / \mathrm{M}_{\mathrm{n}}\right.$ in the range 1.44-1.56 for $\mathbf{1}, 1.34-1.69$ for 2 ). Lowering the amount of initiator to 0.5 equiv per $\mathrm{Cr}^{\mathrm{II}}$ yields a similar trend with lower plateau conversion values and lower initiator efficiency (ca. 0.08 in both cases). This final conversion is again higher with compound 1 (7\%) than with compound $2(5.4 \%)$. Note that the maximum conversion is reached after approximately the same time (ca. $3.5 \mathrm{~h}$ ) for all four experiments.

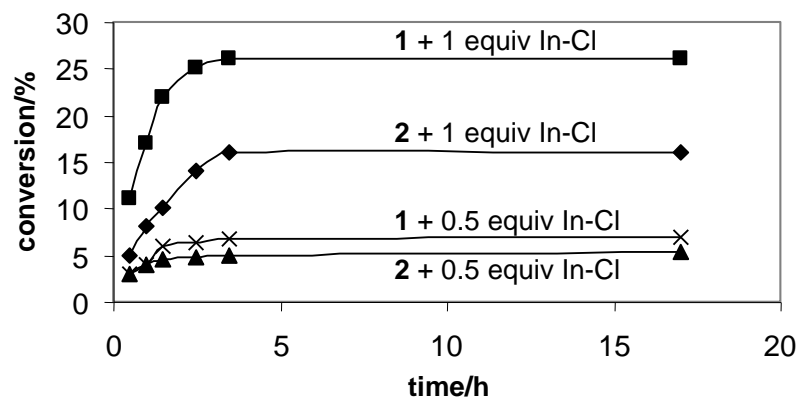

Figure 2. Conversion as a function of time for the VAc polymerization initiated by $\mathrm{CH}_{3} \mathrm{CH}(\mathrm{Cl}) \mathrm{COOCH}_{3}(\mathrm{In}-\mathrm{Cl})$ in the presence of compounds $\mathbf{1}$ and $\mathbf{2}$. Conditions: $\mathrm{VAc} / \mathrm{Cr}^{\mathrm{I}} / \mathrm{CH}_{3} \mathrm{CH}(\mathrm{Cl}) \mathrm{COOCH}_{3}=500: 1:(1$ or 0.5$) . \mathrm{T}=50^{\circ} \mathrm{C}$.

Polymerizations were also carried out with compounds $\mathbf{1}$ and $\mathbf{2}$ under similar conditions with 0.5 equiv of initiator per $\mathrm{Cr}^{\mathrm{II}}$ but now working at room temperature. For both compounds greater conversions were attained relative to the experiments at 
$50^{\circ} \mathrm{C}$. As shown in Figure 3 the monomer consumption is initially rapid but slows over time, although polymerization does not stop, whereas no sustained polymerization had been observed at $50^{\circ} \mathrm{C}$ beyond $3.5 \mathrm{~h}$ (Figure 2). These results suggest the occurrence of a thermal decomposition pathway at $50^{\circ} \mathrm{C}$, which is not prevalent at room temperature. This behavior parallels that of the same polymerization carried out under OMRP conditions and hence suggests that a switch to OMRP control occurs (see Discussion). Like at $50^{\circ} \mathrm{C}$, the conversion attained with 1 are greater than with 2 . The $M_{n}$ deviated little from the theoretical values $\left(M_{n} / M_{n, t h}\right.$ up to a maximum of 2) and the $\mathrm{M}_{\mathrm{w}} / \mathrm{M}_{\mathrm{n}}$ gradually increased throughout the duration of the reaction to a final value of 2.4 with 1 and 1.75 with 2 .

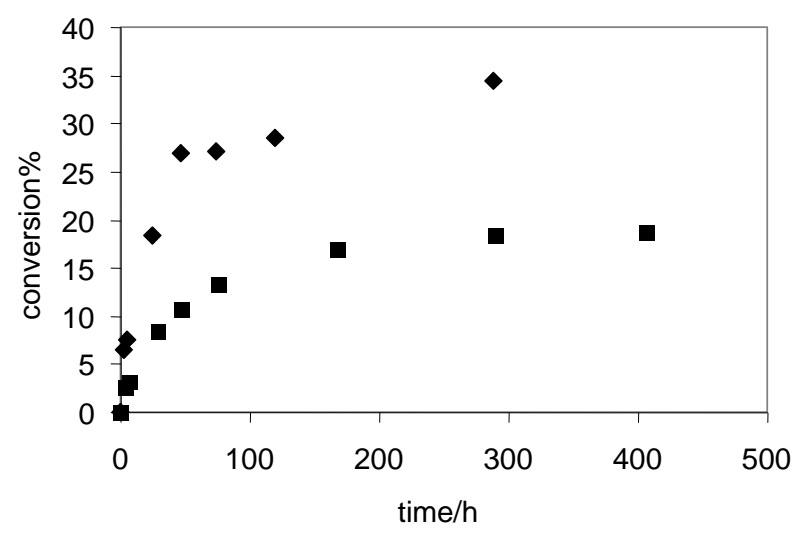

Figure 3. Conversion as a function of time for the VAc polymerization initiated by $\mathrm{CH}_{3} \mathrm{CH}(\mathrm{Cl}) \mathrm{COOCH}_{3}$ (In- $\mathrm{Cl}$ ) in the presence of compound 1 (diamonds) or 2 (squares). Conditions: $\mathrm{VAc} / \mathrm{Cr}^{\mathrm{II}} / \mathrm{CH}_{3} \mathrm{CH}(\mathrm{Cl}) \mathrm{COOCH}_{3}=500: 1: 0.5$. T $=$ room temp.

\section{(b) Reverse ATRP of VAc mediated by complexes 3 and 4}

Polymerization experiments of VAc were also carried out under reverse ATRP 
conditions (in the presence of complexes $\mathbf{3}$ or $\mathbf{4}$ and variable amounts of the azo-compound V-70 as a radical source). The conditions used for the polymerizations and the conversion results are summarized in Figure 4. Polymerizations occurred although, like for the ATRP processes described in the previous section, they reached a plateau and stopped at low monomer conversion. Note that these experiments were also conducted at $50^{\circ} \mathrm{C}$. The polymerizations stopped within the time interval between 5 and $20 \mathrm{~h}$ (the initiator half life at this temperature is ca. $38 \mathrm{~min}$ ) and essentially identical conversions were reached with compounds $\mathbf{3}$ and $\mathbf{4}$ under identical conditions (respectively $32 \%$ and $31 \%$ when using 0.5 equiv of $\mathrm{V}-70 ; 50 \%$ and $46 \%$ when using 1.5 equiv). The polymer characteristics are quite similar to those obtained by the ATRP method (section a): the $M_{\mathrm{w}} / M_{\mathrm{n}}$ values are generally in the 1.4-1.6 range and efficiency factors are low (0.2-0.6, calculated on the basis of $\mathrm{Cr})$.
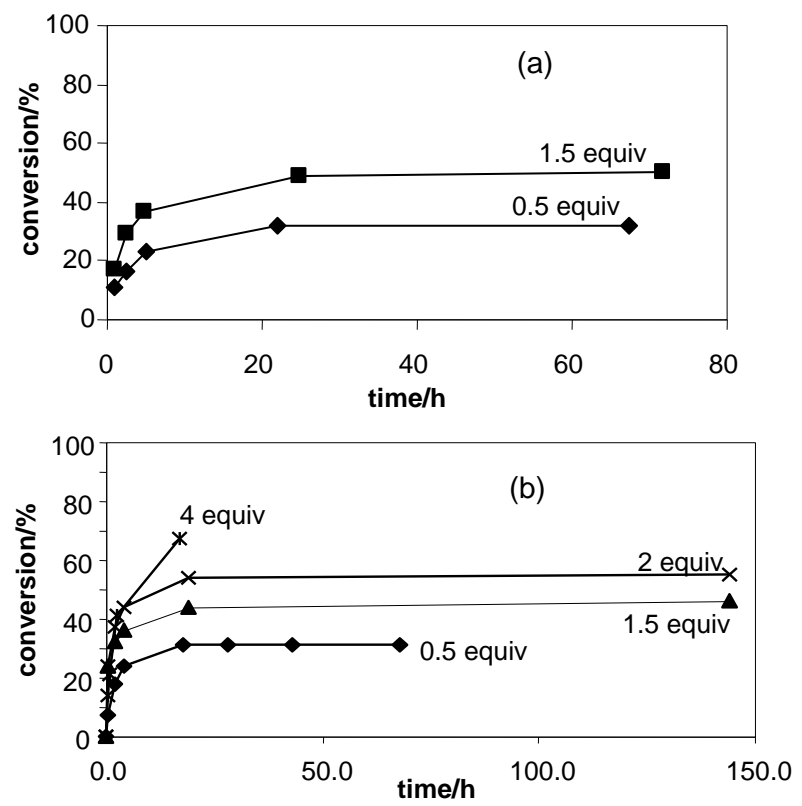

Figure 4. Conversion as a function of time for the VAc polymerization initiated by $\mathrm{V}-70$ in the presence of compound $\mathbf{3}$ (a) or $\mathbf{4}$ (b). Conditions: VAc/Cr/ $/ \mathrm{V}-70$ 


$$
=500: 1:(0.5-4) . \mathrm{T}=50^{\circ} \mathrm{C} \text {. }
$$

\section{(c) Stoichiometric reactions of $\operatorname{CpCr}\left(\operatorname{nacnac}^{\mathrm{Xyl}, \mathrm{Xyl}}\right)$}

Spectroscopic analysis of the VAc polymerization reaction at room temperature in the presence of 2 and 0.5 equiv of the ATRP initiator $\mathrm{CH}_{3} \mathrm{CH}(\mathrm{Cl}) \mathrm{COOCH}_{3}$ showed the complete disappearance of the absorption bands of 2 at $427 \mathrm{~nm}$ and $573 \mathrm{~nm}$ and development of new strong absorption bands at $420 \mathrm{~nm}$ and $581 \mathrm{~nm}$ within $10 \mathrm{~min}$ at room temp. Compound 2 was also reacted with the initiator in the absence of VAc (THF used as solvent) resulting in identical changes in the UV/Vis spectrum within the same timescale. Complex $\mathbf{2}$ also reacts rapidly with phenacyl chloride, $\mathrm{ClCH}_{2} \mathrm{COPh}$ (quantitative conversion upon mixing at room temp), consistent with low $\mathrm{C}-\mathrm{Cl} \mathrm{BDE}$ for substrates with $\alpha-\mathrm{C}(\mathrm{O}) \mathrm{R}$ substituents. ${ }^{22} \mathrm{Cl}$ atom abstraction from these two Cl-substituted species by 2 would result in the formation of 0.5 equiv of $\mathrm{CpCr}\left(\right.$ nacnac $\left.{ }^{\mathrm{Xyl}, \mathrm{Xyl}}\right) \mathrm{Cl}$ and a $\mathrm{CH}_{3} \mathrm{CHCOOCH}_{3}$ or $\mathrm{CH}_{2} \mathrm{COPh}$ radical which will then react with the remaining $\mathrm{Cr}^{\mathrm{II}}$ to form a $\mathrm{Cr}^{\mathrm{III}}$ species. These reactions could potentially form either a $\mathrm{Cr}-\mathrm{C}$ bonded $\left(\mathrm{Cr}-\mathrm{CH}\left(\mathrm{CH}_{3}\right) \mathrm{COOCH}_{3}\right.$ or $\left.\mathrm{Cr}-\mathrm{CH}_{2} \mathrm{COPh}\right)$ or a $\mathrm{Cr}-\mathrm{O}$ bonded $\left(\mathrm{Cr}-\mathrm{OC}\left(\mathrm{OCH}_{3}\right)=\mathrm{CHCH}_{3}\right.$ or $\left.\mathrm{Cr}-\mathrm{OC}(\mathrm{Ph})=\mathrm{CH}_{2}\right)$ product. The UV/Vis spectra from these reactions lacked the distinctive absorption band between 530 and $560 \mathrm{~nm}$ characteristic of $\mathrm{CpCr}\left(\right.$ nacnac)(alkyl) complexes, ${ }^{15-17}$ suggesting the formation of a $\mathrm{Cr}-\mathrm{O}$ bond (Scheme 2). In order to independently synthesize one of these complexes in the absence of $\mathbf{4}$, methyl propionate was deprotonated with $\mathrm{KN}\left(\mathrm{SiMe}_{3}\right)_{2},{ }^{26}$ and the isolated potassium enolate was reacted with $\mathrm{CpCr}\left(\operatorname{nacnac}^{\mathrm{Xyl}, \mathrm{Xyl}}\right) \mathrm{I} \cdot{ }^{17}$ Although X-ray 
quality crystals of the resulting $\mathrm{Cr}^{\mathrm{III}}$ enolate complex $\mathrm{CpCr}\left(\right.$ nacnac $\left.^{\mathrm{Xyl}, \mathrm{Xyl}}\right)\left[\mathrm{OC}\left(\mathrm{OCH}_{3}\right)=\mathrm{CHCH}_{3}\right]$ could not be obtained, the corresponding reaction sequence with acetophenone provided suitable crystals of $\mathrm{CpCr}\left(\right.$ nacnac $\left.^{\mathrm{Xyl}, \mathrm{Xyl}}\right)\left[\mathrm{OC}\left(=\mathrm{CH}_{2}\right) \mathrm{Ph}\right], \quad 5$. Complex 5 co-crystallized with $\sim 10 \%$ of unreacted $\mathrm{Cr}$ (III) iodide starting material, a problem that was also observed in the structure of $\mathrm{CpCr}\left(\right.$ nacnac $\left.{ }^{\text {Dep,Dep }}\right)\left(\mathrm{CH}_{3}\right) .{ }^{17}$ However, the structure confirmed the bonding mode of the organic fragment as an enolate bound through oxygen. The large $\mathrm{Cr}-\mathrm{O}-\mathrm{C}$ bond angle of $\mathbf{5}$ (Figure 5) is consistent with an O-bound enolate ligand as opposed to a C-bound ligand which would be expected to have a considerably smaller bond angle. In addition, the two hydrogen atoms bound to $\mathrm{C} 27$ were clearly visible during structural refinements of the crystallographic data for compound $\mathbf{5}$ and consistent with $\mathrm{sp}^{2}$ hybridization at the carbon atom. As the UV/Vis spectra of both enolate complexes are very similar, we propose that the $\mathrm{CpCr}\left(\right.$ nacnac $\left.^{\mathrm{Xyl}, \mathrm{Xyl}}\right)\left[\mathrm{OC}\left(\mathrm{OCH}_{3}\right)=\mathrm{CHCH}_{3}\right]$ complex also has a $\mathrm{Cr}-\mathrm{O}$ bond. Isolated $\mathrm{CpCr}\left(\right.$ nacnac $\left.^{\mathrm{Xyl}, \mathrm{Xyl}}\right)\left[\mathrm{OC}\left(\mathrm{OCH}_{3}\right)=\mathrm{CHCH}_{3}\right]$ did not initiate the polymerization of vinyl acetate, at room temp or when heated to $50^{\circ} \mathrm{C}$.

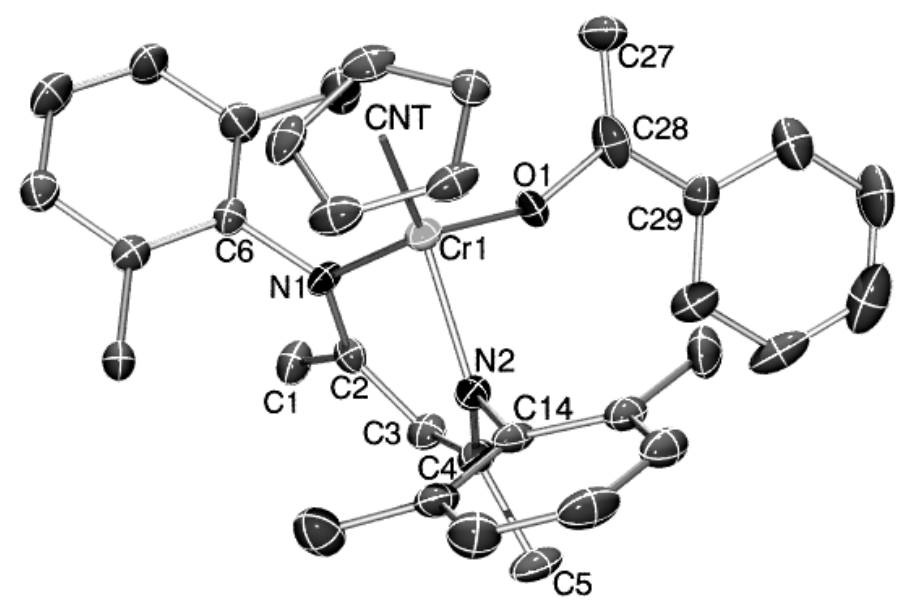


Figure 5. Thermal ellipsoid diagram $(50 \%)$ of compound 5. Compound 5 co-crystallizes with approx. $10 \%$ iodide starting material; the I atom of the co-crystallized starting material and all $\mathrm{H}$ atoms are omitted for clarity. Selected bond lengths $(\AA)$ : $\mathrm{Cr}(1)-\mathrm{N}(1), 2.007(3) ; \operatorname{Cr}(1)-\mathrm{N}(2), 2.023(3)$; $\mathrm{Cr}(1)-\mathrm{CNT}, \quad 1.925 ; \quad \mathrm{Cr}(1)-\mathrm{O}(1), \quad 1.878(4) ; \quad \mathrm{O}(1)-\mathrm{C}(28), \quad 1.367(18)$; $\mathrm{C}(27)-\mathrm{C}(28)$, 1.37(3). Selected bond angles (deg): $\mathrm{N}(1)-\mathrm{Cr}(1)-\mathrm{N}(2)$, 89.61(13); $\mathrm{N}(1)-\mathrm{Cr}(1)-\mathrm{O}(1), 90.26(15) ; \mathrm{N}(2)-\mathrm{Cr}(1)-\mathrm{O}(1), 91.07(15)$; CNT-Cr(1)-O(1), 126.17; Cr(1)-O(1)-C(28), 145.9(12).

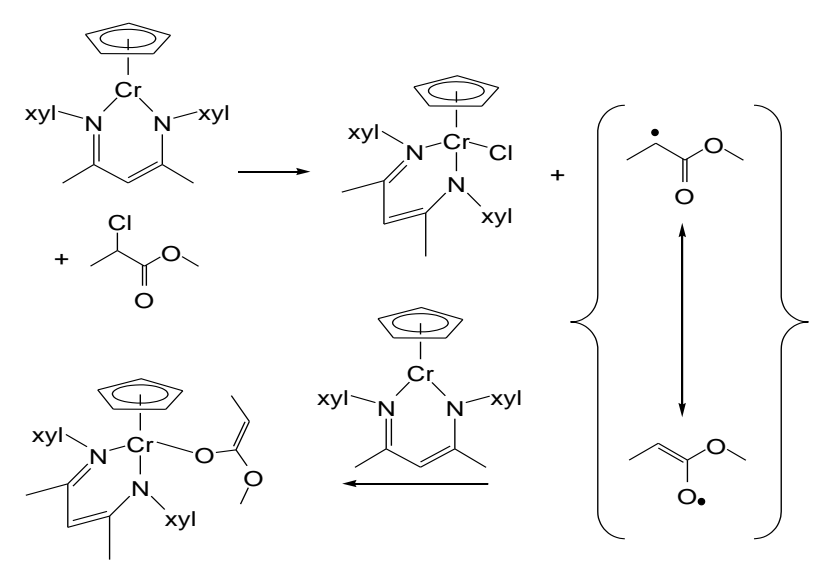

\section{Scheme 2}

In contrast with the above fast reactions, compound $\mathbf{2}$ reacted much more slowly with one equiv of either 1-chloroethyl acetate or chloromethyl pivalate at room temperature (significant conversion after $24 \mathrm{~h}$ ), and no reaction of 2 with neopentyl chloride was observed at room temp or at $50^{\circ} \mathrm{C}$ (UV/Vis). In these cases, the UV/Vis monitoring gave clear evidence of the formation of $\mathbf{4}$ and a $\mathrm{Cr}^{\mathrm{III}}$ alkyl product (broad band at $\sim 550 \mathrm{~nm})$. Interestingly, whereas the absorption assigned to the putative $\mathrm{CpCr}\left(\right.$ nacnac $\left.^{\mathrm{Xyl}, \mathrm{Xyl}}\right)\left[\mathrm{CH}\left(\mathrm{OOCCH}_{3}\right) \mathrm{CH}_{3}\right]$ product decreased in intensity at extended

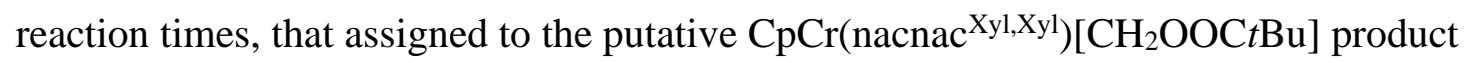
maintained its intensity unaltered, suggesting greater stability for the alkyl compound 
with the primary alkyl group.

\section{(d) DFT studies}

We have decided to recur to DFT calculations in order to address several issues.

A first issue is the relative stabilities of the ATRP and OMRP dormant states with respect to the active radical. The 1-chloroethyl acetate molecule was chosen as a suitable model for the PVAc-Cl dormant chain of the ATRP process, whereas the $\mathrm{CpCr}\left(\right.$ nacnac $\left.^{\mathrm{Ar}, \mathrm{Ar}}\right)(\mathrm{CHMeOAc})$ was considered suitable to model the $\mathrm{CpCr}\left(\right.$ nacnac $\left.^{\mathrm{Ar}, \mathrm{Ar}}\right)(\mathrm{PVAc})$ dormant chain of the OMRP process. The relative energy of the latter and the steric effect of the Ar group (Ph, Xyl, Dipp) on the $\mathrm{Cr}-\mathrm{C}$ bond dissociation energy has already been calculated and presented in our previous contribution. ${ }^{15}$ The previous study also included the calculation of the transition state for the OMRP trapping process. Therefore, the new calculations of the chloride complexes and of the transition states for the ATRP activation/deactivation process for the three aryl systems were conducted at the same level of theory (see Experimental Section for details). The energetic results are summarized in Figure 6 and the transition state geometries are shown in Figure 7. 


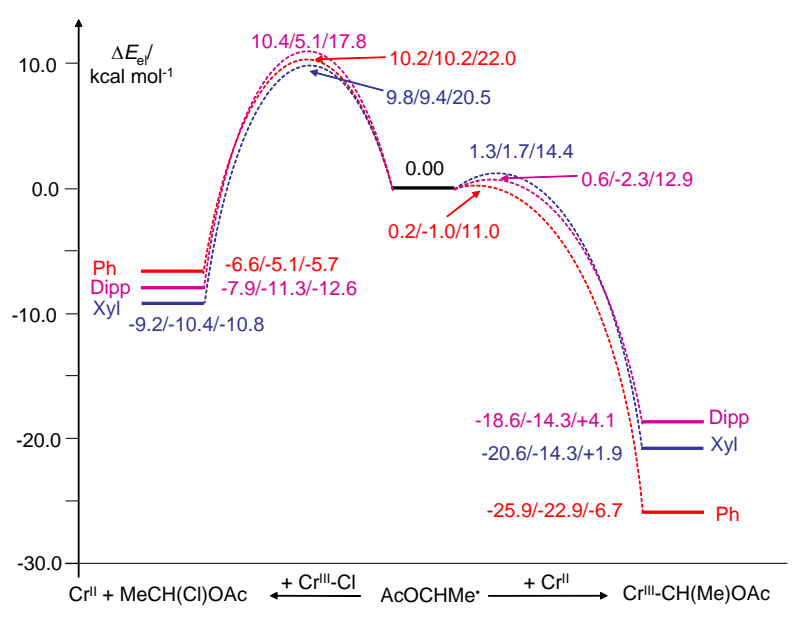

Figure 6. Energy diagram for the ATRP and OMRP activation/deactivation involving the $\mathrm{CpCr}^{\mathrm{II}}\left(\right.$ nacnac $\left.{ }^{\mathrm{Ar}, \mathrm{Ar}}\right)$ and $\mathrm{CH}_{3} \mathrm{CH}(\mathrm{Cl}) \mathrm{OAc}$ systems $(\mathrm{Ar}=\mathrm{Ph}$, red; Xyl, blue; Dipp, purple). For each localized energy minimum or transition state, the three given numbers indicate respectively the change of electronic energy $\left(\Delta E_{\mathrm{el}}\right)$, enthalpy $(\Delta H)$ and Gibbs free energy $(\Delta G)$ in $\mathrm{kcal} / \mathrm{mol}$. The data are plotted on the $\Delta E_{\text {el }}$ scale.

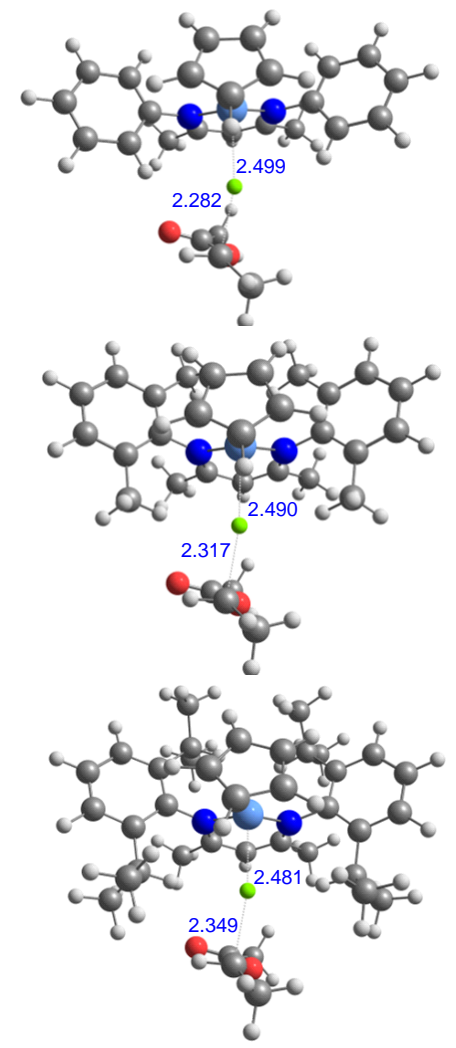

Figure 7. Geometries of the transition states for the ATRP activation/deactivation process involving the $\mathrm{Ph}$ (above), Xyl (middle) and Dipp (below) systems. 
The calculations indicate that the ATRP dormant state is less favored than the OMRP dormant state for all Ar substituents at the $\Delta E_{\text {el }}$ and $\Delta H$ levels. Only when introducing the gas-phase (-TS) term, i.e. going to the $\Delta G$ level, the stability order is inverted (only for Xyl and Dipp systems). In solution, however, the major portion of the entropy term (translational + rotational) is partially quenched by the solvent lattice and the actual change of $G$ is expected to differ from the gas-phase value and to be closer to the $\Delta H$ value. The calculations also indicate that the steric effect operated by the Ar substituents is more pronounced on the OMRP activation/deactivation equilibrium (difference between the $\mathrm{Ph}$ and Dipp systems of 7.3, 8.6 and $10.8 \mathrm{kcal}$ $\mathrm{mol}^{-1}$ at the $\Delta E_{\mathrm{el}}, \Delta H$, and $\Delta G$ levels) than on the ATRP equilibrium (corresponding differences of 1.3, 6.2 and $6.9 \mathrm{kcal} \mathrm{mol}^{-1}$ ), because the smaller size of the $\mathrm{Cl}$ atom relative to the $\mathrm{CH}\left(\mathrm{CH}_{3}\right) \mathrm{OAc}$ fragment induces a less severe rearrangement of the coordination sphere on going from $\mathrm{Cr}^{\mathrm{II}}$ to $\mathrm{Cr}^{\mathrm{III}}$. A greater steric hindrance disfavors the active state for the ATRP equilibrium and the dormant state for the OMRP equilibrium, so $\Delta G_{\text {ATRP }}$ increases in the order $\mathrm{Ph}<\mathrm{Xyl}<\mathrm{Dipp}$ (the same holds for $\Delta H_{\mathrm{ATRP}}$, whereas an inversion is predicted at the $\Delta E_{\mathrm{el}, \mathrm{ATRP}}$ level, see Figure 6) and $\Delta G_{\text {OMRP }}$ increases in the opposite order and by a greater extent. Finally, the calculations indicate that the energetic barrier leading from the active radical to the ATRP dormant state is much greater than that leading to the OMRP dormant state. Whereas the latter is almost non existent at the $\Delta E^{*}$ el and $\Delta H^{*}$ levels (negative values are obtained after the PV correction for the Ph and Dipp systems) and in the 10-15 
$\mathrm{kcal} \mathrm{mol}{ }^{-1}$ range at the gas-phase $\Delta G^{\ddagger}$ level, the former is ca. $10 \mathrm{kcal} \mathrm{mol}^{-1}$ at the $\Delta E^{\ddagger}$ el and $\Delta H^{\ddagger}$ levels and $>20 \mathrm{kcal} \mathrm{mol}^{-1}$ at the $\Delta G^{\ddagger}$ level. The geometries obtained for the ATRP transition states are very similar for the three systems and little dependent on the aryl steric requirements. As the steric bulk increases, the transition state is earlier along the $\mathrm{Cl}$ atom transfer coordinate, with a shorter $\mathrm{Cr}-\mathrm{Cl}$ and a longer $\mathrm{Cl}-\mathrm{C}$ distance, because of the greater steric push exerted by the nacnac ligand while regaining its more relaxed conformation in the 2-legged piano stool configuration of the $\mathrm{Cr}^{\mathrm{II}}$ complex.

The difference between OMRP and ATRP trapping barriers at the $\Delta H^{\ddagger}$ level can be easily rationalized since OMRP trapping involves a simple bond making process and is therefore only requiring a small coordination sphere reorganization to allow the accommodation of the new ligand, whereas ATRP trapping involves simultaneous bond breaking and making processes. The PVAc $^{\circ}$ growing chains are therefore predicted to be trapped much more rapidly by the $\mathrm{Cr}^{\mathrm{II}}$ complex than by the $\mathrm{Cr}^{\mathrm{III}}-\mathrm{Cl}$ complex. Note that, although the (-TS) term has nearly no effect on the thermodynamics of the ATRP equilibrium $\left(\Delta H_{\mathrm{ATRP}} \approx \Delta G_{\mathrm{ATRP}}\right)$ because the reaction conserves the number of molecules, the activation process is very much affected by the entropy term because of the associative character of the atom transfer process. In conclusion, OMRP trapping is both thermodynamically and kinetically favored over ATRP trapping.

We have also explored the activation of compound $\mathrm{CH}_{3} \mathrm{CH}(\mathrm{Cl}) \mathrm{COOCH}_{3}$ by complex 2, as well as the relative stability of the C-bonded and O-bonded $\mathrm{Cr}^{\mathrm{III}}$ 
complexes formed by addition of the $\mathrm{CH}_{3} \mathrm{CHCOOCH}_{3}$ radical to 2 , namely compounds $\mathrm{CpCr}\left(\right.$ nacnac $\left.^{\mathrm{Xyl}, \mathrm{Xyl}}\right)\left(\mathrm{CH}\left(\mathrm{COOCH}_{3}\right) \mathrm{CH}_{3}\right) \quad$ and $\mathrm{CpCr}\left(\operatorname{nacnac}^{\mathrm{Xyl}, \mathrm{Xyl}}\right)-$ $\left(\mathrm{OC}\left(\mathrm{OCH}_{3}\right)=\mathrm{CHCH}_{3}\right)$. We limited these calculations to the thermodynamics, without optimization of the relevant transition states. The relative energy of $\mathbf{2}+$ $\mathrm{CH}_{3} \mathrm{CH}(\mathrm{Cl}) \mathrm{COOCH}_{3}$ with respect to $4+\mathrm{CH}_{3} \mathrm{CHCOOCH}_{3}$, is $+1.4,-0.8$ and $-1.6 \mathrm{kcal}$ mol $^{-1}$ at the $\Delta \mathrm{E}, \Delta \mathrm{H}$, and $\Delta \mathrm{G}$ levels, respectively. The more favorable activation of $\mathrm{CH}_{3} \mathrm{CH}(\mathrm{Cl}) \mathrm{COOCH}_{3}$ relative to $\mathrm{CH}_{3} \mathrm{CH}(\mathrm{Cl}) \mathrm{OOCCH}_{3}$ (Figure 6) is caused by its weaker $\mathrm{C}-\mathrm{Cl}$ bond (BDE of -68.4 for the former $v s .-79.0$ for the latter). Even though the transition state for the $\mathrm{Cl}$ atom transfer process was not optimized in this case, the activation energy can be easily predicted to be lower than for the methyl 2-cloroproprionate, because the $\mathrm{C}-\mathrm{Cl}$ bond breaking process requires less energy while the $\mathrm{Cr}-\mathrm{Cl}$ bond making process provides the same thermodynamic drive. This result is in line with the experimental observations: the stoichiometric reaction of $\mathbf{2}$ with $\mathrm{CH}_{3} \mathrm{CH}(\mathrm{Cl}) \mathrm{COOCH}_{3}$ is rapid whereas that with $\mathrm{CH}_{3} \mathrm{CH}(\mathrm{Cl}) \mathrm{OOCCH}_{3}$ is slow. The adduct formation between the $\mathrm{CH}_{3} \mathrm{CHCOOCH}_{3}$ radical and complex 2 provides a stabilization energy of $-15.8 \mathrm{kcal} \mathrm{mol}^{-1}$ for the $\mathrm{C}$ bonded form and $-17.6 \mathrm{kcal} \mathrm{mol}^{-1}$ for the O-bonded ( $\alpha$-methoxy enolate) form. On the $\Delta H$ scale, these bond energies become -9.4 and $-14.3 \mathrm{kcal} \mathrm{mol}^{-1}$, respectively. Hence, the enolate form is calculated as the more stable one. Both isomers, however, have a smaller bond dissociation energy than the OMRP dormant species of the PVAc model system $\left(\mathrm{CH}_{3} \mathrm{CHOOCCH}_{3}\right.$ radical). 


\section{Discussion}

The polymerization results show that the ATRP initiator $\mathrm{CH}_{3} \mathrm{CH}(\mathrm{Cl}) \mathrm{COOCH}_{3}$ is activated by $\mathrm{CpCr}^{\mathrm{II}}$ (nacnac) (compounds $\mathbf{1}$ and 2) to start a slow polymerization of VAc. The initiator is also found to react with $\mathbf{2}$ in the absence of monomer, to presumably yield a mixture of $\mathbf{3}$ and the enolate complex $\mathrm{CpCr}\left(\right.$ nacnac $\left.^{\mathrm{Xyl}, \mathrm{Xyl}}\right)\left[\mathrm{OC}\left(\mathrm{OCH}_{3}\right)=\mathrm{CHCH}_{3}\right]$ (Scheme 2). Indeed, the DFT calculations show that the enolate is more stable than the C-bonded form of the $\mathrm{CH}_{3} \mathrm{CHCOOCH}_{3}$ radical. In the presence of VAc, the primary $\mathrm{CH}_{3}\left(\mathrm{COOCH}_{3}\right) \mathrm{CH}^{\bullet}$ radical has the choice to either react with a molecule of $\mathrm{CpCr}^{\mathrm{II}}$ (nacnac) to irreversibly yield the $\mathrm{Cr}^{\mathrm{III}}$ enolate, or add to monomer to start the PVAc chain growth. The very low initiator efficiency observed for the process is likely related to the competitive trapping by chromium and indeed complex $\mathrm{CpCr}\left(\right.$ nacnac $\left.{ }^{\mathrm{Xyl}, \mathrm{Xyl}}\right)\left[\mathrm{OC}\left(\mathrm{OCH}_{3}\right)=\mathrm{CHCH}_{3}\right]$ was shown to be incapable to reinitiate polymerization. This low initiator efficiency factor could not be caused by extensive radical coupling termination during initiation, because a significant build-up of $\mathrm{Cr}^{\mathrm{II}}$, which would necessarily accompany such irreversible terminations, was not observed for these reactions.

Once the primary radical has started a PVAc chain, reversible trapping of this chain occurs as indicated by the sustained polymerization, even though the level of control is poor. Thus, a dormant species is formed. Of the two possible trapping processes, namely ATRP and OMRP, the latter must be preferentially operating, as indicated by a combination of experimental and theoretical evidence. On the 
experimental side, the reaction between compound 2 and $\mathrm{CH}_{3} \mathrm{CH}(\mathrm{Cl}) \mathrm{OAc}$, which has a C-Cl bond strength very close to that of the putative PVAc-Cl dormant species, was shown to be relatively slow. The evolution of the polymerization rate at $25^{\circ} \mathrm{C}$ (Figure 3 ) is in fact quite similar to that of the corresponding polymerization initiated by $\mathrm{CpCr}{ }^{\mathrm{III}}\left(\right.$ nacnac $\left.^{\mathrm{Xyl}, \mathrm{Xyl}}\right)\left(\mathrm{CH}_{2} \mathrm{CMe}_{3}\right)$ under the same conditions, which is necessarily controlled by the OMRP equilibrium. ${ }^{15}$ The decrease of the polymerization rate with time and the deactivation at higher temperature have been completely rationalized in the previous OMRP study as resulting from occasional head-to-head monomer insertions followed by acetate group transfer, leading to the inactive $\mathrm{CpCr}\left(\right.$ nacnac $\left.{ }^{\mathrm{Xyl}, \mathrm{Xyl}}\right)(\mathrm{OAc})$ compound. ${ }^{15}$ Hence, the trend of polymerization rate is additional persuasive evidence that the VAc polymerization is moderated by the OMRP equilibrium also when it is initiated by the ATRP initiator. It is not surprising that similar results are also obtained under reverse ATRP conditions.

The computational results confirm the above conclusion and allow other interesting considerations. Faster activation of the more active methyl 2-chloropropionate relative to 1-chloroethyl acetate is also indicated by the DFT study. ATRP reactivation of the dormant PVAc-Cl chains (modeled by 1-chloroethyl acetate) is predicted to require a barrier of 30.4 and $31.3 \mathrm{kcal} \mathrm{mol}^{-1}$ on the $\Delta G^{\ddagger}$ scale, or 16.4 and $19.8 \mathrm{kcal} \mathrm{mol}^{-1}$ on the $\Delta H^{*}$ scale, for compounds $\mathbf{1}$ and $\mathbf{2}$, respectively. These values are greater than those of the OMRP activation $\left(12.5\right.$ and $8.8 \mathrm{kcal} \mathrm{mol}^{-1}$ on the $\Delta G^{\ddagger}$ scale, or 16.0 and $12.0 \mathrm{kcal} \mathrm{mol}^{-1}$ on the $\Delta H^{\ddagger}$ scale, for the Xyl and Dipp systems, respectively) and consistent with the relatively slow reaction between complex 2 and 
compound $\mathrm{CH}_{3} \mathrm{CH}(\mathrm{Cl}) \mathrm{OAc}$. At any rate, the most important parameter determining the nature of the moderating mechanism is the trapping rate, which is strongly in favor of the OMRP process.

The dynamics of this polymerization process can be understood as follows (refer to Scheme 3). When the polymerization is initiated by $\mathrm{CH}_{3} \mathrm{CH}(\mathrm{Cl}) \mathrm{COOMe}$ in the presence of $\mathbf{1}$ or $\mathbf{2}, \mathrm{Cl}$ atom transfer occurs to generate the $\mathrm{Cr}{ }^{\mathrm{III}}$ chloro complex (3 or $\left.\mathbf{4}\right)$ and the stabilized $\mathrm{CH}_{3}(\mathrm{COOMe}) \mathrm{CH}^{*}$ radical, which is either trapped by a second molecule of the $\mathrm{Cr}^{\mathrm{II}}$ complex to yield an inactive $\mathrm{Cr}^{\mathrm{III}}$ enolate or adds to the VAc monomer. The non-stabilized PVAc ${ }^{\bullet}$ radical is then trapped more rapidly by additional $\mathrm{Cr}^{\mathrm{II}}$ complex than by the $\mathrm{Cr}^{\mathrm{III}}$ chloro complex and subsequent chain growth is regulated by the OMRP equilibrium. Under reverse ATRP conditions (initiation by $\mathrm{V}-70$ in the presence of complex $\mathbf{3}$ or $\mathbf{4}$ ), the primary radical adds to VAc and the resulting $\mathrm{PVAc}^{\bullet}$ radical can only be trapped by $\mathrm{Cr}^{\mathrm{III}}-\mathrm{Cl}$, since no $\mathrm{Cr}^{\mathrm{II}}$ complex is initially present. However, slow $\mathrm{Cl}$ atom transfer yields irreversibly $\mathrm{PVAc}-\mathrm{Cl}$ and $\mathrm{Cr}^{\mathrm{II}}$. While PVAc-Cl is only very slowly reactivated according to an ATRP mechanism, compound $\mathbf{2}$ is now available to trap additional $\mathrm{PVAc}^{\bullet}$ chains and install the OMRP equilibrium. The reaction stops before complete monomer conversion when carried out at $50^{\circ} \mathrm{C}$, because of a decomposition process of the OMRP dormant species to yield an acetate complex $\mathrm{CpCr}^{\mathrm{III}}($ nacnac)(OAc), as detailed in our previous contribution. ${ }^{15}$ 


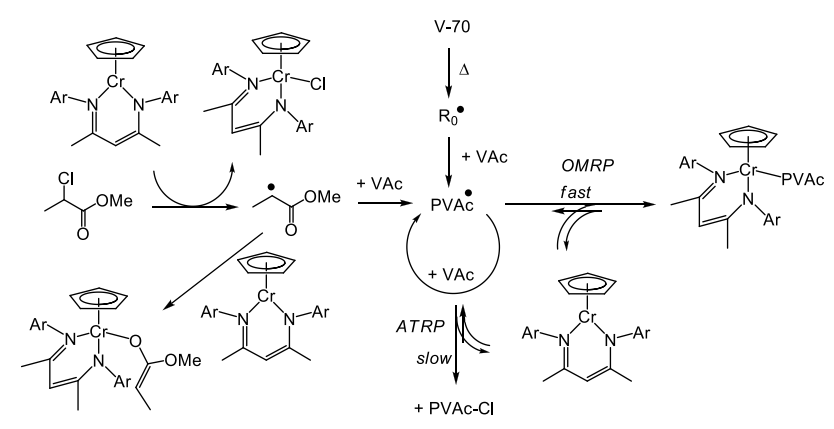

\section{Scheme 3}

\section{Conclusions}

This contribution has served to illustrate the general principle that interplay between atom transfer and metal-carbon bond formation for the radical trapping in controlled radical polymerization may thermodynamically favor formation of the organometallic dormant species and has shown the first reported example where this is proven to occur. The contribution also shows, by computation of the activation barriers of the two competitive radical trapping processes, that the metal-carbon bond formation is greatly preferred for the kinetic standpoint. Although this is intuitively obvious, a clear statement to this effect and the explicit calculation of the two competitive barriers had not yet been reported to the best of our knowledge.

The system investigated here has no significant value for the practical development of efficient controlled polymerization protocols for vinyl acetate, a challenging monomer, because of a variety of problems. The low initiator efficiency factors related to the competitive formation of $\mathrm{Cr}^{\mathrm{III}}$ enolates might be easily eliminated through the use of other sources of stabilized radicals devoid of conjugated 
$\mathrm{O}$ atoms, for instance $\mathrm{PhCH}(\mathrm{Cl}) \mathrm{CH}_{3}$. Sustained polymerization is however hampered by acetate transfer to the oxophilic metal center. This process has so far not been observed for cobalt systems, which appear so far the best ones for controlling the radical polymerization of this monomer. However, the half-sandwich $\mathrm{Cr}$ system reported here has been useful to better appreciate the scope of the ATRP-OMRP interplay.

Acknowledgement. We are grateful to the Agence Nationale de la Recherche (contract ANR No. NT05-2_42140) for financial support. RP also thanks the Institut Universitaire de France for additional support and the Centre Interuniversitaire de Calcul de Toulouse (CICT, project CALMIP) and the Centre Informatique National de l'Enseignement Supérieur (CINES) for granting free computational time. KMS thanks the Natural Sciences and Engineering Research Council of Canada (NSERC), the Canadian Foundation for Innovation, and the University of British Columbia for financial support.

Supporting Information Available. Tables of $\mathrm{M}_{\mathrm{n}}$ and PDI vs. conversion for all polymerizations; key geometrical parameters for the optimized geometries; Cartesian coordinates for all new optimized geometries; complete crystallographic data for complex 5 (16 pages).

\section{References}


Satoh, K.; Kamigaito, M., Chem. Rev. 2009, 109, 5120-5156.

Destarac, M.; Charmot, D.; Franck, X.; Zard, S. Z., Macromol. Rapid Commun. 2000, 21, 1035-1039.

Rizzardo, E.; Chiefari, J.; Mayadunne, R.; Moad, G.; Thang, S., Macromol. Symp. 2001, 174, 209-212.

Rizzardo, E.; Chiefari, J.; Mayadunne, R. T. A.; Moad, G.; Thang, S. H., ACS Symp. Ser. 2000, 768, 278-296.

Stenzel, M. H.; Cummins, L.; Roberts, G. E.; Davis, T. P.; Vana, P.; Barner-Kowollik, C., Macromol. Chem. Phys. 2003, 204, 1160-1168.

Yamago, S., Proc. Jpn. Acad. Ser. B-Phys. Biol. Sci. 2005, 81, 117-128.

Debuigne, A.; Caille, J. R.; Jérôme, R., Angew. Chem., Int. Ed. Eng. 2005, 44, 1101-1104.

Maria, S.; Kaneyoshi, H.; Matyjaszewski, K.; Poli, R., Chem. Eur. J. 2007, 13, 2480-2492.

Debuigne, A.; Champouret, Y.; Jérôme, R.; Poli, R.; Detrembleur, C., Chem. Eur. J. 2008, 14, 4046-4059.

Debuigne, A.; Poli, R.; Jérôme, R.; Jérôme, C.; Detrembleur, C., ACS Symp. Ser. 2009, 1024, 131-148.

Debuigne, A.; Poli, R.; Jérôme, C.; Jérome, R.; Detrembleur, C., Prog. Polym. Sci. 2009, 34, 211-239.

Poli, R., Angew. Chem., Int. Ed. Engl. 2006, 45, 5058-5070.

Smith, K. M., Coord. Chem. Rev. 2006, 250, 1023-1031.

Champouret, Y.; Baisch, U.; Poli, R.; Tang, L.; Conway, J. L.; Smith, K. M., Angew. Chem., Int. Ed. Engl. 2008, 47, 6069-6072.

Champouret, Y.; Macleod, K. C.; Baisch, U.; Patrick, B. O.; Smith, K. M.; Poli, R., Organometallics 2010, 29, 167-176.

Doherty, J. C.; Ballem, K. H. D.; Patrick, B. O.; Smith, K. M., Organometallics 2004, 23, 1487-1489.

Macleod, K. C.; Conway, J. L.; Tang, L. M.; Smith, J. J.; Corcoran, L. D.; Ballem, K. H. D.; Patrick, B. O.; Smith, K. M., Organometallics 2009, 28, 6798-6806.

Le Grognec, E.; Claverie, J.; Poli, R., J. Am. Chem. Soc. 2001, 123, 9513-9524.

Matyjaszewski, K.; Woodworth, B. E., Macromolecules 1998, 31, 4718-4723.

Braunecker, W. A.; Itami, Y.; Matyjaszewski, K., Macromolecules 2005, 38, 9402-9404.

Braunecker, W. A.; Brown, W. C.; Morelli, B.; Tang, W.; Poli, R.; Matyjaszewski, K., Macromolecules 2007, 40, 8576-8585.

Gillies, M. B.; Matyjaszewski, K.; Norrby, P.-O.; Pintauer, T.; Poli, R.; Richard, P., Macromolecules 2003, 36, 8551-8559.

Pangborn, A. B.; Giardello, M. A.; Grubbs, R. H.; Rosen, R. K.; Timmers, F. J., Organometallics 1996, 15, 1518-1520.

Armarego, W. L. F.; Perrin, D. D., Purification of Laboratory Chemicals. ed.; Butterworth Heinemann, 4th ed.: 1996.

Zakrzewski, J., Chromatographia 2004, 59, 775-777.

Culkin, D. A.; Hartwig, J. F., J. Am. Chem. Soc. 2001, 123, 5816-5817.

SAINT, version 7.03A. ed.; Bruker Analytical X-ray System: Madison, WI, USA, 1997-2003. TWINABS, Bruker Nonius scaling and absoption for twinned crystals - V2008/2. ed.; Bruker AXS Inc.: Madison, Wisconsin, 2008. 
Altomare, A.; Cascarano, G.; Giacovazzo, C.; Guagliardi, A., J. Appl. Cryst. 1993, 26, 343-350. Sheldrick, G. M., SHELXTL, version 5.1. ed.; Bruker AXS, Inc.: Madison WI, 1997.

Farrugia, L. J., J. Appl. Crystallogr. 1997, 32, 565.

Frisch, M. J., et al., Gaussian 03, Revision D.01. ed.; Gaussian, Inc.: Wallingford CT, 2004.

Becke, A. D., J. Chem. Phys. 1993, 98, 5648-5652.

Rappé, A. K.; Casewit, C. J.; Colwell, K. S.; Goddard Iii, W. A.; Skiff, W. M., J. Am. Chem Soc. 1992, 114, 10024-10035.

Ehlers, A. W.; Boehme, M.; Dapprich, S.; Gobbi, A.; Hoellwarth, A.; Jonas, V.; Koehler, K. F.; Stegmann, R.; Veldkamp, A.; Frenking, G., Chem. Phys. Lett. 1993, 208, 111-114. 


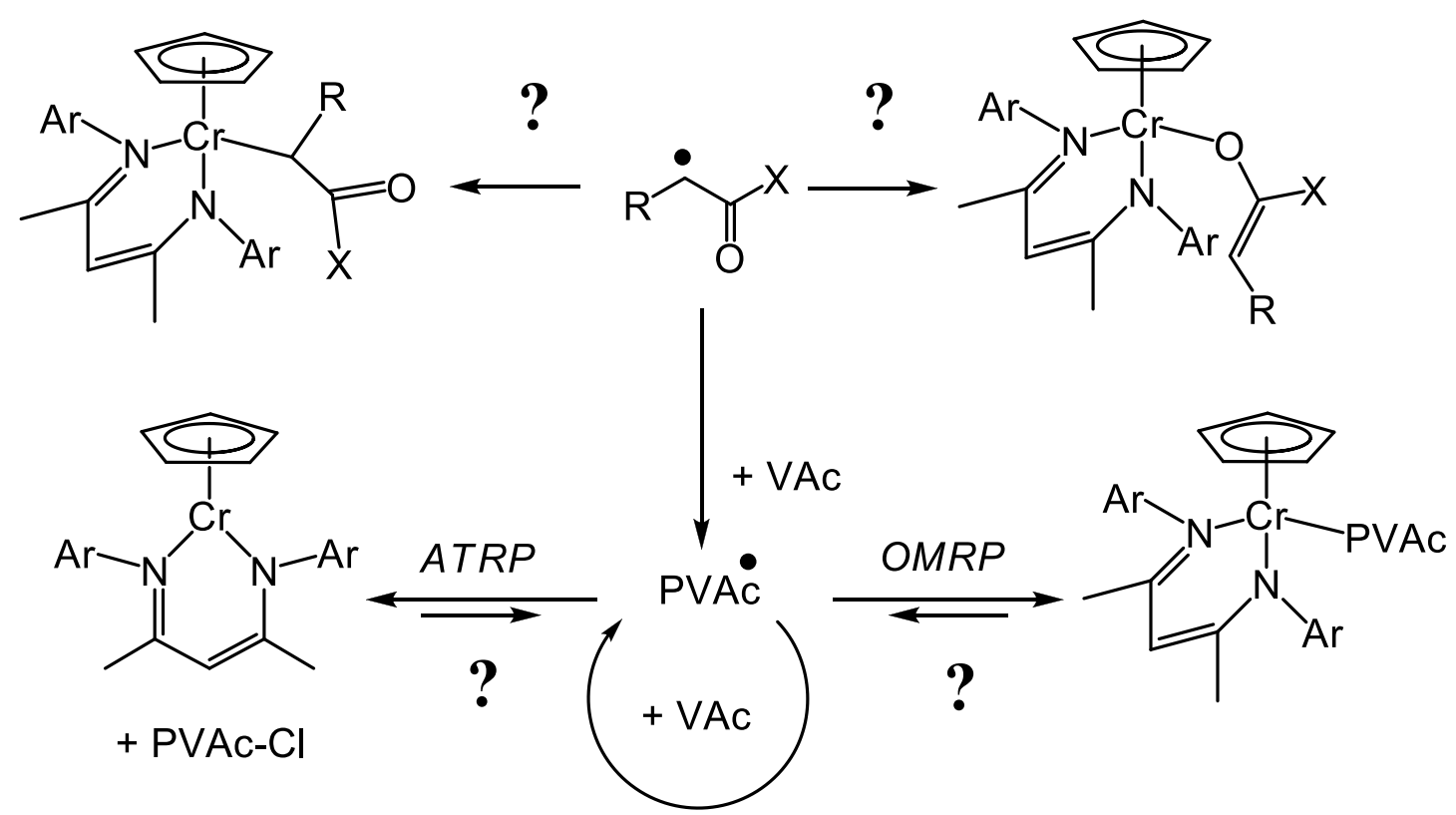

\section{Table of Contents Text}

Use of a half-sandwich $\mathrm{Cr}^{\mathrm{II}} / \mathrm{Cr}^{\mathrm{III}}$ system to control the radical polymerization of vinyl acetate has revealed for the first time that the interplay between two moderating mechanism, atom transfer radical polymerization (ATRP) and organometallic mediated radical polymerization (OMRP), may lie in favor of the latter, both kinetically and thermodynamically. 